\title{
Hubungan Riwayat Imunisasi dengan Status Gizi Balita
}

\author{
Siti Nurhasiyah Jamil ${ }^{*}$, Aning Subiyatin \\ Program Studi Kebidanan Program Sarjana dan Profesi Bidan \\ Fakultas Kedokteran dan Kesehatan Universitas Muhammadiyah Jakarta \\ *Email korespondensi: sitinurhasiyahjamil@umj.ac.id
}

\begin{abstract}
Article Info
ABSTRACT

Article history:

Submitted: 2020-05-15

Accepted: $2020-08-16$

Published: 2020-08-30

Keywords:

Nutrition status; toddlers; immunization history;

The toddler period is a period that must be observed property, at this time the direction of child development will be determined for the next period. The purpose of this study was to study the immunization status of nutritional status in infants. The research design used was cross-sectional in the work area of Johar Baru Health Center, Jakarta Pusat, which was conducted from AprilJune 2019. The population of all children aged 6-59 months, while the study sample was infants with stunting of 105 respondents, which is data child nutrition in Health Center. Data processing and analysis using SPSS with Chi-Square statistical test, the confidence level of $95 \%$. The results of variables related to the nutritional status of children under five are the relationship of immunization $\mathrm{P}$ value $(0.004 \mathrm{OR}$ and $\mathrm{Cl}(0.173(0.051-0.59)$. The conclusion of the variable related to the nutritional status of underfive children is immunization.
\end{abstract}

Kata kunci:

Status gizi; balita; riwayat imunisasi;

\section{ABSTRAK}

Masa balita merupakan suatu periode yang harus dicermati dengan benar, pada masa tersebut akan menentukan arah tumbuh kembang anak untuk periode selanjutnya. Tujuan penelitian untuk mengetahui peran imunisasi sebagai faktor protektif status gizi pada balita. Design penelitian yang digunakan desain Cross sectional di Puskesmas wilayah kerja Johar Baru, Jakarta Pusat, yang dilaksanakan dari bulan April-Juni 2019. Populasinya semua anak usia 6-59 bulan, sedangkan sampel seluruh bayi yang menderita stunting sejumlah 105 responden, yang merupakan data gizi anak di puskesmas. Pengolahan dan analisa data menggunakan SPSS. Uji statistik yang digunakan uji chi square, tingkat kepercayaan 95\%. Hasil variable yang berhubungan dengan status gizi balita adalah riwayat imunisasi $\mathrm{P}$ value (0.004 OR dan $\mathrm{Cl}$ (0.173(0.051-0.59). Simpulan varibel yang berhubungan dengan status gizi balita adalah riwayat imunisasi. 


\section{PENDAHULUAN}

Masa balita merupakan suatu periode penting dalam tumbuh kembang anak karena masa balita akan menentukan perkembangan anak di masa selanjutnya. Pada masa tersebut adalah periode emas dalam tumbuh kembang fisik dan kecerdasan. Untuk itu perlu adanya dukungan status gizi yang baik guna menentukan upaya peningkatan sumberdaya manusia. ${ }^{1}$ Kualitas generasi yang akan datang juga dipengaruhi keadaan gizi saat ini, terutama pada masa balita. Akibat gizi buruk dan gizi kurang akan mempengaruhi kualitas kehidupannya kelak. Akibat kekurangan gizi pada interval ini dapat berakibat pada kecatatan, angka kesakitan meningkat dan prematuriras. ${ }^{2}$

Indonesia termasuk dalam 17 negara yang memiliki tiga masalah gizi pada anak balita: stunting, wasting, dan kelebihan berat badan., ${ }^{3,4}$ Laporan Riset Kesehatan Dasar Indonesia tahun 2018 menunjukan prevalensi gizi buruk sebesar $3,8 \%$ dan gizi kurang 11,4\%. Angka ini turun jika dibanding tahun 2007 yang prevalensi gizi buruk 5,4\% dan gizi kurang $13.0 \%$ dan tahun 2013 yang prevalensi gizi buruk sebesar $5,7 \%$ dan gizi kurang $13.9 \% .^{5-7}$ dengan Untuk propinsi DKI Jakarta tahun 2018 prevalensi gizi buruk sebesar 1,5\% dan gizi kurang $11,7 \%{ }^{7}$

Berdasarkan Laporan di DKI Jakarta tahun 2017 balita di Bawah garis Merah (BGM) sebesar 5898 kasus (sebesar 1,5\%). Tahun 2016 ditemukan 937 kasus $(0,47 \%)$. Hal lain dilaporkan adanya temuan baduta dibawah garis merah (BGM) di wilayah Jakarta Pusat sebesar 5,94\%, diikuti Jakarta Barat sebesar 3,13\%.8.9

Masalah kekurangan gizi pada balita tidak terjadi secara spontan, kenaikan BB yang lambat dan tdk sesuai usianya merupakan indikator awal masalah gizi pada balita. ${ }^{10}$ Penyebab masalah gizi dipengaruhi dua faktor yaitu faktor langsung dan tidak langsung, adapun secara langsung dipengaruhi konsumsi makanan kurang bergizi dan keadaan kesehatan individu. Peran kedua faktor juga berhubungan dengan rendahnya pendapatan sehingga tidak terpenuhinya kebutuhan dasar. ${ }^{10-12}$ Selain hal tersebut menurut Supariasa, 2002 dikatakan status gizi balita akan berhubungan dengan pendidikan orang tua, pekerjaan, jumlah anak, pengetahuan dan pola asuh ibu serta kondisi ekonomi secara keseluruhan. ${ }^{13}$

Faktor lain yang juga mempunyai peran penting adalah jumlah anak dan jarak kelahiran yang terlalu dekat. Dalam hal ini walalupun ekonomi cukup maka berpengaruh pada perhatian dan kasih sayang orang tua terhadap anak. Sedangkan jumlah anak yang banyak juga berpengaruh kepada keluarga karena kurangnya perhatian orang tua kepada anaknya meskipun keluarga tersebut secara ekonomi berkecukupan. ${ }^{13}$

Status gizi balita juga erat kaitannya dengan status gizi ibu sebelum dan selama kehamilan. Status gizi yang kurang pada masa kehamilan akan mempengaruhi tumbuh kembang janin dalam kandungan dan akan melahirkan bayi dengan Berat Badan Lahir Rendah (BBLR) bahkan kematian. Jika hal ini tidak ditangani dengan benar maka akan menimbulkan masalah gizi pada balita dikemudian hari, karena seribu hari pertama pada anak merupakan periode emas dan kritis dam tumbuh kembang fisik, mental, dan sosialnya. ${ }^{2}$ Tujuan penelitian ini adalah untuk mengetahui hubungan status imunisasi dengan status gizi balita.

\section{METODE PENELITIAN}

Penelitian menggunakan desain Cross sectional di Puskesmas wilayah kerja Johar Baru, Jakarta Pusat, yang dilaksanakan dari bulan April-Juni 2019. Populasinya semua anak usia 6-59 bulan, sedangkan sampelnya seluruh bayi 
stunting sejumlah 105 responden. Penentuan status gizi berdasarkan indikator $\mathrm{BB} / \mathrm{U}$. Data yang digunakan adalah data sekunder. Pengumpulan data diperoleh dari data laporan gizi puskesmas.

Variabel dependen pada penelitian ini adalah status gizi balita, sedangkan variabel independennya adalah pendidikan ayah, pendidikan ibu, riwayat kehamilan, riwayat imunisasi, dan jumlah anak.

Pengolahan dan analisa data menggunakan SPSS. Uji statistik yang digunakan uji chi square dengan tingkat kepercayaan $95 \%$.

\section{HASIL PENELITIAN}

\section{Karakteristik Responden}

Tabel 2. Distribusi Frekuensi Jenis Kelamin, Pendidikan Ayah, Pendidikan Ibu, Riwayat Kehamilan, Riwayat Imunisasi dengan Status Gizi Balita

\begin{tabular}{lcc}
\hline Variabel & Frekuensi & Persentase (\%) \\
\hline $\begin{array}{l}\text { Jenis Kelamin } \\
\text { Laki-laki }\end{array}$ & 47 & 44.8 \\
$\quad$ Perempuan & 58 & 55.2 \\
$\begin{array}{l}\text { Pendidikan Ayah } \\
\quad \text { Rendah }\end{array}$ & & \\
$\quad$ Tinggi & 41 & 39.0 \\
Pendidikan lbu & 64 & 61.0 \\
$\quad$ Rendah & & \\
$\quad$ Tinggi & 63 & 60.0 \\
Riwayat Kehamilan & 42 & 40.0 \\
$\quad$ KEK & & \\
$\quad$ Non KEK & 11 & 10.5 \\
Riwayat Imunisasi & 94 & 89.5 \\
$\quad$ Tidak Lengkap & & \\
$\quad$ Lengkap & 15 & 14.3 \\
Jumlah Anak & 90 & 85.7 \\
$\quad$ <3 & & \\
$\quad$ >3 & 68 & 64.8 \\
$\quad$ Status Gizi & 37 & 35.2 \\
$\quad$ Kurang & & \\
Baik & 65 & 61.9 \\
\hline
\end{tabular}

Dari tabel 2 dapat diketahui bahwa mayoritas balita dengan jenis kelamin perempuan $(55,2 \%)$. Pendidikan ayah sebagian besar dengan latar belakang pendidikan tinggi (61\%), adapun pendidikan rata-rata ayah SMP, paling banyak SMA, PT sebanyak 5 responden pada variabel pendidikan ibu mayoritas ibu memiliki latar belakang pendidikan rendah $(60 \%)$. Pendidikan ibu rata-rata SMP, paling banyak SMA dan ada yang perguruan tinggi sebesar 4 responden. Para riwayat kehamilan mayoritas dengan kehamilan non KEK (89,5\%). Pada variabel riwayat imunisasi mayoritas dengan status imunisasi lengkap (85,7\%). Pada variabel jumlah anak mayoritas ibu dengan anak $<3(64,8 \%)$. Dari tabel 1 dapat diketahui mayoritas balita di wilayah kerja puskesmas Johar Baru Jakarta Pusat mengalami gizi kurang yaitu sebesar $61,9 \%$. 


\section{Hubungan antar variabel dengan status gizi balita}

Tabel 2: Hubungan Pendidikan Ayah, Pendidikan lbu, Riwayat Kehamilan, Riwayat Imunisasi dengan Status Gizi Balita

\begin{tabular}{|c|c|c|c|c|c|c|}
\hline \multirow{3}{*}{ Variabel } & \multicolumn{4}{|c|}{ Status gizi } & \multirow{3}{*}{$p$-value } & \multirow{3}{*}{ OR (Cl) } \\
\hline & \multicolumn{2}{|c|}{ Kurang } & \multicolumn{2}{|c|}{ Baik } & & \\
\hline & $\mathbf{n}$ & $\%$ & $\mathbf{n}$ & $\%$ & & \\
\hline \multicolumn{7}{|l|}{ Pendidikan Ayah } \\
\hline Rendah & 26 & 63.4 & 15 & 36.6 & 0.961 & \\
\hline Tinggi & 39 & 60.0 & 25 & 39.1 & & \\
\hline \multicolumn{7}{|l|}{ Pendidikan Ibu } \\
\hline Rendah & 38 & 60.3 & 25 & 39.7 & 0.837 & \\
\hline Tinggi & 27 & 64.3 & 15 & 35.7 & & \\
\hline \multicolumn{7}{|l|}{ Riwayat Kehamilan } \\
\hline KEK & 8 & 72.7 & 3 & 27.3 & 0.526 & \\
\hline Non KEK & 57 & 60.6 & 37 & 39.4 & & \\
\hline \multicolumn{7}{|l|}{ Riwayat Imunisasi } \\
\hline Tidak Lengkap & 4 & 26.7 & 11 & 73.3 & 0.004 & $0.17(0.0-0.5)$ \\
\hline $\begin{array}{c}\text { Lengkap } \\
\text { Jumlah Anak }\end{array}$ & 61 & 67.8 & 29 & 32.2 & & \\
\hline$<3$ & 42 & 61.8 & 26 & 38.2 & 1.000 & \\
\hline$>3$ & 23 & 62.2 & 14 & 37.8 & & \\
\hline
\end{tabular}

Pada tabel 2 berdasarkan hasil uji statistik pada riwayat imunisasi yang tidak lengkap diperoleh $p$-value $=0,004$ yang artinya ada hubungan bermakna antara status imunisasi yang tidak lengkap dengan status gizi balita dengan nilai OR 0,173 yang artinya nilai OR kurang 1 berarti imunisasi adalah faktor protektif atau faktor pencegah status gizi kurang. Sedangkan variabel pendidikan ayah, pendidikan ibu, riwayat kehamilan, dan jumlah anak berdasarkan hasil analisis ditemukan tidak ada hubungan dengan status gizi balita.

\section{PEMBAHASAN}

Pendidikan ayah dan ibu dalam penelitian ini tidak berhubungan dengan status gizi balita. Tingkat pendidikan orang tua mempunyai andil dalam pertumbuhan balita. Peran pendidikan dalam kesehatan dan tumbuh kembang baita salah satunya yaitu dalam hal pemilihan bahan pangan. Orang yang memiliki pendidikan tinggi maka cenderung mempunyai pengetahuan yang baik, mudah dalam menerima dan megembangkan teknologi yang dapat meningkatkan produktivitas dan kesejahteraan keluarga serta dalam memilih kualitas maupun kuantitas pangan. ${ }^{10}$ Semakin tinggi pendiikan maka semakin baik status gizi anak, selain itu ibu merupakan manajer dalam rumah tangga, sehingga tingkat pendidikan ibu juga punya peran penting dalam penyerapan informasi gizi dan kesehatan. Ibu dengan pendidikan yang lebih tinggi akan mudah menyerap ilmu dibandingkan dengan ibu yang berpendidikan rendah. ${ }^{14}$

Riwayat kehamilan dalam penelitian ini tidak memiliki hubungan dengan status gizi balita, hal ini tidak sejalan yang ditemukan Devi, 2010 yang mengatakan bahwa alternative memutus siklus hayati kekurangan gizi yaitu dengan status gizi dan kesehatan ibu hamil yang merupakan penentu generasi yang akan datang. Hal inilah yang menjadi dasar pencegahan kurang gizi pada masa janin. Intervensi selama kehamilan berupa pemberian tablet $\mathrm{Fe}$ untuk mencegah anemia dan pemenuhan gizi yang baik pada ibu hamil bertujuan untuk perbaikan komposisi tumbuh kembang janin yang akan mempengaruhi pertumbuhannya di masa akan datang. Selain hal 
tersebut diatas Devi juga mengungkapkan bahwa keadaan kekurangan gizi sebelum dan selama kehamilan mempunyai andil dalam penambahan angka kelahiran BBLR, dan kematian bayi. Tumbuh kembang fisik, mental, soisal dan otak $80 \%$ terjadi pada masa tersebut, sehingga masa ini merupakan penentu kualitas sumberdaya manusia (SDM) yang akan datang, terutama intelegency quantity yang rendah. ${ }^{2}$ Hasil penelitian ini juga tidak sejalan dengan yang diungkapkan Sarlis dan Ivanna, 2018 bahwa penyebab kekurangan gizi pada anak berkaitan dengan asupan gizi yang kurang, yang mana berhubungan secara langsung dengan kondisi social dan ketersediaan makanan yang adekuat. ${ }^{15}$

Hasil analisis jumlah anak tidak berhubungan dengan status gizi. Peran jarak kelahiran yang terlalu dekat dan jumlah anak yang banyak dalam asupan gizi keluarga sangatlah besar, banyak anak dengan jarak yang dekat akan memungkinkan seorang ibu akan mengalami kesulitan mengurus dan menciptakan suasana tenang di rumah. Kasus kurang gizi hampir 4 kali lebih banyak ditemukan pada keluarga besar dibandingkan degan keluarga kecil, sehingga anak-anak dari keluarga tersebut lebih banyak yang kurus, punya daya pikir yang lemah, kurang darah, dan terserang penyakit. Maka diharapkan keluarga kecil mempunyai tingkat kesejahteraan yang terjamin dalam pemenuhan kebutuhan pangan dibandingkan keluarga jumlah besar. ${ }^{1}$

Temuan dalam penelitian ini juga tidak sejalan dengan yang Putri, dkk, 2015 lakukan yang mengungkapkan bahwa jumlah anak yang banyak dan jarak yang terlalu dekat akan mengakibatkan berkurangnya perhatian dan kasih sayang orang tua, sehingga akan berakibat menurunnya nafsu makan dan berdampak pada status gizinya. ${ }^{13}$

Satu-satunya variabel yang berhubungan dengan status gizi balita dalam penelitian ini adalah status imunisasi yang kurang lengkap dengan p-value 0,004. Pemberian imunisasi pada anak bertujuan untuk mengurangi risiko morbiditas (kesakitan) dan mortalitas (kematian) pada anak. Status imunisasi juga merupakan indicator kontak dengan pelayanan kesehatan, artinya dengan status imunisasi yang lengkap maka akan memperbaiki masalah gizi baru, sehingga status imunisasi juga diharapkan akan memberikan efek positif terhadap status gizi jangka panjang. ${ }^{14}$

\section{SIMPULAN DAN SARAN}

Hasil penelitian mayoritas balita di wilayah kerja puskesmas Johar Baru Jakarta Pusat dengan status gizi kurang. Hasil analisis bivariat diperoleh $p$-value $<005$ pada balita dengan riwayat imunisasi yang kurang lengkap. Tidak ada hubungan yang bermakna antara pendidikan ayah, pendidikan ibu, riwayat kehamilan dan jumlah anak.

peneliti berharap pihak puskesmas lebih proaktif dalam meningkatkan kegiatan penyuluhan tentang pentingnya imunisasi dan pengetahuan gizi yang berkaitan dengan zat-zat gizi, pada ibu hamil dan anak, makanan pendamping ASI (MPASI), menu seimbang, pola asuh dan perawatan anak serta keluarga sadar gizi dan mengoptimalkan kegiatan promosi kesehatan dengan memasyarakatkan pedoman gizi seimbang melalui RW siaga, meningkatkan kegiatan surveilans agar faktorfaktor yang terkait dengan kurang gizi dapat terdeteksi secara dini.

\section{UCAPAN TERIMA KASIH}

Penelitian ini tidak terlepas dari dukungan dari berbagai pihak untuk itu peneliti ingin menyampaikan ucapan terima kasih kepada Fakultas Kedokteran dan Kesehatan Universitas Muhammadiyah Jakarta (FKK UMJ) yang telah memberikan bantuan 
baik secara moril maupun materiil. Tak lupa pula ucapan terima kasih kami sampaikan kepada Puskesmas Johar Baru Jakarta Pusat yang telah berkenan memberikan ijin pada peneliti untuk melakukan penelitian ini. Terakhir kami ucapkan terima kasih kepada ibu Hamidah SST, MKM selaku kaprodi kebidanan FKK UMJ yang memberikan dukungan kepada para dosen untuk selalu meneliti, beserta teman dosen yang tidak bisa disebutkan satu persatu yang telah banyak membantu dalam proses penelitian ini.

\section{DAFTAR PUSTAKA}

1. Lutviana E, Budiono I. Prevalensi Dan Determinan Kejadian Gizi Kurang Pada Balita 2010. KEMAS J Kesehat Masy [Internet]. 2010;5(2). Available from: https://journal.unnes.ac.id/nju/index.php/kemas/article/view/1872

2. Devi M. Analisis Faktor-Faktor yang Berpengaruh terhadap Status Gizi Balita di Pedesaan. J Teknol Kejuruan, dan Pengajarannya [Internet]. 2010;33(2). Available from: http://journal.um.ac.id/index.php/teknologi-kejuruan/article/view/3054

3. Rahmawati VE, Pamungkasari EP, Murti B. Determinants of Stunting and Child Development in Jombang District. J Matern Child Heal [Internet]. 2018;03(01):68-80. Available from: http://thejmch.com/index.php?journal=thejmch\&page=article\&op=view\&path\%5B\%5D $=81 \&$ path $\% 5 B \% 5 \mathrm{D}=91$

4. Ramadhan K. Status Gizi menurut Tinggi Badan per Umur pada Balita. Poltekita J Ilmu Kesehat. 2020 Apr 27;13(2):96-101.

5. Kementerian Kesehatan R.I. Riset Kesehatan Dasar (RISKESDAS) 2007 [Internet]. Jakarta: Badan Penelitian dan Pengembangan Kesehatan Kementerian Kesehatan RI; $2007 . \quad$ Available from: http://labdata.litbang.kemkes.go.id/images/download/laporan/RKD/2007/lap_rkd07.pdf

6. Kementerian Kesehatan R.I. Riset Kesehatan Dasar 2013 [Internet]. Jakarta: Badan Penelitian dan Pengembangan Kesehatan Kementerian Kesehatan RI; 2013. Available from: http://labdata.litbang.kemkes.go.id/images/download/laporan/RKD/2013/Laporan_risk esdas_2013_final.pdf

7. Kementerian Kesehatan R.I. Laporan Riskesdas 2018 [Internet]. Jakarta: Badan Penelitian dan Pengembangan Kesehatan Kementerian Kesehatan RI; 2018. Available from: http://www.yankes.kemkes.go.id/assets/downloads/PMK No. 57 Tahun 2013 tentang PTRM.pdf

8. Dinas Kesehatan Propinsi DKI Jakarta. Profil Kesehatan Propinsi DKI Jakarta Tahun 2017 [Internet]. Jakarta: Dinas Kesehatan Propinsi DKI Jakarta; 2018. 1-156 p. Available from: https://dinkes.jakarta.go.id/wp-content/uploads/2019/12/PROFILKESEHATAN-DKI-JAKARTA-TAHUN-2017.pdf

9. Dinas Kesehatan Propinsi DKI Jakarta. Profil Kesehatan Propinsi DKI Jakarta Tahun 2016. Jakarta: Dinas Kesehatan Propinsi DKI Jakarta; 2017.

10. Suzanna S, Budiastutik I, Marlenywati M. Analisis Faktor yang Berhubungan dengan Status Gizi Anak Usia 6-59 Bulan. J Vokasi Kesehat [Internet]. 2017 Jan 31;3(1):35. Available from: http://ejournal.poltekkespontianak.ac.id/index.php/JVK/article/view/103

11. Fikawati S, Syafiq A, Veratamala A. Gizi Anak dan Remaja. Depok: Raja Grafindo; 2017.

12. Sudirman H. Stunting atau Pendek Awal Perubahan Patologia atau Adaptasi Karena Perubahan Sosial Ekonomi yang Berkepanjangan. Media Penelit dan Pengemb Kesehat [Internet]. 2008;18(1):33-42. Available from: http://ejournal.litbang.kemkes.go.id/index.php/MPK/article/view/713

13. Putri RF, Sulastri D, Lestari Y. Faktor-Faktor yang Berhubungan dengan Status Gizi Anak Balita di Wilayah Kerja Puskesmas Nanggalo Padang. J Kesehat Andalas 
[Internet]. 2015 Jan 1;4(1):254-61. Available from: http://jurnal.fk.unand.ac.id/index.php/jka/article/view/231

14. Maxwell S. Module 5: Causes of Malnutrition [Internet]. Available from: https://www.ennonline.net/module5\#

15. Sarlis N, Ivanna CN. Faktor-Faktor yang Berhubungan dengan Status Gizi Balita di Puskesmas Sidomulyo Pekanbaru. J Endur [Internet]. 2018 Mar 19;3(1):146. Available from: http://ejournal.kopertis10.or.id/index.php/endurance/article/view/2074 